on long-range nuclear weapons. In parallel, there is a case for beginning negotiations on nuclear weapons based in Europe recognizing, at the same time, that the technicalities of this problem are formidable. The feasibility of a comprehensive testban treaty has receded, but it should not be forgotten that, just a year ago, officials in the then United States Administration were saying that only a month or so was needed to bring the treaty to a conclusion. These are only some of the avenues that might usefully be explored. The need is not to keep Chancellor Helmut Schmidt in office (for he can look after himself, and should be doing so more effectively) but to demonstrate to Western Europe and the rest of the world that the agreement within the West on which the whole theory of deterrence has been based has not, since January, become a dead letter. For President Reagan, the delicate first task is somehow to persuade the United States military, together with a substantial part of the American electorate, that they like others can live with arms control.

\section{One hope retracted}

The news that Professor Efraim Racker has found it necessary to withdraw from publication a paper read at the Cold Spring Harbor Tumor Virus Symposium last May, and has in the process cast doubt on several related papers, is a cruel disappointment. For several years it has been apparent that in the understanding of the causation of cancers of various kinds, the most clamant need has been for a mechanism of some generality that would explain how it comes about that carcinogens of very different kinds (chemicals such as benzpyrene, radiation or just age) can cause malignant diseases that take on a life of their own. Mr Mark Spector's account of how the products of RNA tumour viruses, more often known as retroviruses, might affect the biochemistry of a cell, promised to be just such a mechanism. If, indeed, a succession of steps, chemically similar, amounting to the phosphorylation of successive protein in a hierarchy of protein kinases had been involved in the manifestation of cancer caused by retroviruses, it would have been relatively easy to understand how different carcinogenic agents might affect different steps in the ladder.

So what has gone wrong? That is what people working in the field will now be asking. And those members of Congress who have been wringing their hands for the past few months about the warts on the fair face of science, and who have only grudgingly accepted the assurances offered them by the scientific community, will no doubt be opening yet another inquiry into what seems to be yet another case of inexplicable error. At this stage, it is far too soon to guess what Congress will make of what has been happening at Cornell, but certainly the circumstances do not resemble those of the cases of outright deception that have created such a sense of shock in the past eighteen months. First, the people who have blown the whistle on this occasion include many of the authors of the original and now suspect research. Second, it is reported that some parts of the proposed mechanism of carcinogenesis were accurately described. Third, retraction has been swift and none of the participants seems to have benefited personally, even in the intangible ways that often go with successful innovation in such a spectacular field.

Unfortunately, that cannot be an end to the affair. Selfdeception, when published, is also culpable. On this occasion, the conspicuous case of self-deception seems to have been that of $\mathrm{Mr}$ Mark Spector, by all accounts a dedicated graduate student given to herculean labours. The question will, however, be raised whether those among his seniors who put their names to his account of his research can emerge unscathed from the mess that has been created. The difficulty is that by convention - not merely a convention of the scientific literature but of scholarship and intellectual intercourse in general - people who put their names to a publication must be able to defend what has been said. Again on the face of things, this seems not to have been the case at Cornell. After the Cold Spring Harbor meeting, Professor Racker seems to have checked his junior colleague's work. Should he not have been there at the beginning?.

What, in these unhappy circumstances, should be done? Internally, as a free-standing university of some repute, Cornell needs to discover for itself what has gone wrong. With a little luck, it may discover that there is something to be salvaged. There is, however, a chance that it may also discover that there is something wrong in the usual relationship between junior and senior investigators (who spend respectively too much and too little time at the bench). The awkward truth about experimental investigations is that no amount of preliminary planning and no amount of eventual statistical analysis (or some other form of assistance) can adequately substitute for having measured something or having observed it. Those whose administrative and other extra-laboratory responsibilities are too pressing to permit the strict observance of this rule should acknowledge the risks that they are running. And those in Congress who have been speculating, during this year's seemingly endless inquiries on the question of falsification, that the penalties of failure have become intolerably great, should now give some thought to the possibility that the rewards of success have also been too great.

\section{Students vote with feet}

In the British system of higher education, this is the most poignant season of the year. For this is when would-be students who have been refused by the universities to which they first applied for entry are matched (by the Universities' Central Council on Admissions) with the vacancies still left within the system. The euphemism for the process is the "clearing". The process is largely mechanical. Students have already declared their interests, and the council's computer can be reckoned on to ensure that the best qualified among such would-be students as wish to spend the rest of their lives in the study of, say, Sanskrit will find their way to the establishments offering instruction in such arcane pursuits. In reality, of course, there is no conspicuous institution within the British educational system that offers to gratify such ambitions. There are, however, many universities that have informed the central computer that they could accommodate so many students in modern languages, the humanities, medicine and the sciences.

Last week, the council put out a statement to the schools warning head teachers that, this year, the "clearing" would find places in higher education for fewer people - perhaps half as many - than it was able to accommodate last year. Would-be scientists will be frequently disappointed, for young people (no doubt by a quick reading of job advertisements in the newspapers) have apparently worked out that technical skills are more marketable than other kinds of skills. The result is that would-be Sanskrit students are even more likely to be satisfied by the clearing, and that more would-be scientists than ever will join the dole queues.

This is a multi-dimensional nonsense. The University Grants Committee, remarking that science and its application is probably in the national interest, as well as the upturn in enthusiasm among young people, has decreed that the numbers of students on science courses should be reduced by a smaller proportion than the numbers of students following other kinds of courses. But there is nevertheless to be a reduction, of the order of five per cent in the next three years. The difficulty is that nobody can at this stage know whether the willingness of universities to educate different kinds of students corresponds with the government's intentions. Some may even have compromised with the wish of their Sanskrit teachers (and the like) to retain their tenured posts. Accordingly, nobody should think of crying scandal if it turns out, when the "clearing" is done with, that the dole queues are more richly endowed with would-be scientists than with other disappointed university students. That, after all, is how the system has been constructed. The tragedy is that in the first year in ten in which there has been a substantial resurgence of interest in learning science, British universities should have found themselves unable to respond. 